\title{
Konsistensi Indonesia sebagai Kekuatan Menengah: Studi Kasus Respon Deterrence di Natuna
}

\author{
Amy Debora \\ 2014330072 \\ Mahasiswa Ilmu Hubungan Internasional, Fakultas Ilmu Sosial dan Ilmu Politik \\ Universitas Katolik Parahyangan
}

\begin{abstract}
Abstrak
As Jakarta is working to resolve the South China Sea (SCS) territorial dispute through its role as an honest broker, Beijing seems to lead the SCS conflict right into the foremost defense of the Republic of Indonesia. This is indicated by the China Coast Guard (CCG) aggressive actions in guarding illegal fishing in Natuna Sea. The conflict escalation raises the question of whether Natuna will enter into the SCS territorial dispute. However, these concerns did not occur due to the appropriate response of Jakarta in maintaining the stability of the region without undermining its defense of its territorial sovereignty. Significantly strengthening the defense in Natuna does not create a security dilemma for ASEAN member countries as it is done in conjunction with the border diplomacy effort. This shows the success of border diplomacy as indirect deterrence against China. This paper will be divided into 4 sections, first the author will give an overview of the SCS conflict and the threats to maritime security in Natuna. Next will be described the concept of 'middlepowermanship' according to Cooper, Higgot and Nossal who states that the middle power is reflected from the characteristics of foreign policy. This paper finds that the response reflects the Indonesia's consistency as a middle power. Proved by Indonesia's niche diplomacy under Jokowi administration, as well as the role of Jakarta as coalition builder for ASEAN.
\end{abstract}

Keywords: South China Sea, middle power, Indonesian foreign policy, deterrence, diplomacy

"China respects strength if they see you as being weak, they will eat you alive"

- Dewi Fortuna Anwar, foreign policy adviser.

\section{Latar Belakang}

Power menjadi faktor dominan dalam perumusan politik luar negeri (PLN) suatu negara. Pertimbangan antara bagaimana negara memandang sumber-sumber power yang dimilikinya dan power seperti apa yang ingin diperlihatkan negara dalam hubungan internasional akan mempengaruhi politik luar negeri. Power negara diperlihatkan dengan 2 bentuk, yaitu status dan peran. Power sebagai status ditunjukkan dari faktor geografis seperti letak wilayah atau kekayaan sumber daya

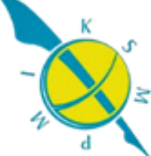


alam, kapasitas militer, pertumbuhan ekonomi, perdagangan internasional yang aktif hingga populasi penduduk. Sedangkan power sebagai peran dilihat dari kemampuan negara berdiplomasi atau bagaimana respon negara menanggapi kerja sama maupun konflik antar negara. ${ }^{1}$ Apapun respon negara, politik luar negeri tetap berorientasi pada kepentingan nasional. Bagi Indonesia sendiri, stabilitas kawasan Asia Pasifik merupakan kepentingan esensial. Setiap bentuk ancaman keamanan harus dihilangkan untuk menciptakan stabilitas kawasan untuk memastikan iklim investasi yang kondusif.

Konflik LCS merupakan konflik sengketa wilayah yang berlarut-larut di kawasan Asia Tenggara. LCS merupakan salah satu jalur pelayaran tersibuk di dunia dengan nilai perdagangan internasional tidak kurang dari 5,3 triliun dolar AS per tahun. ${ }^{2}$ Selain itu, minyak yang didistribusikan melalui LCS berjumlah tiga kali lipat lebih banyak dari minyak yang melewati Terusan Suez dan 15 kali lipat dari jumlah minyak yang melintasi Terusan Panama. ${ }^{3}$ Untuk itu, negara-negara perlu meramu kebijakan luar negerinya di maritime superhighway ini. Sengketa wilayah LCS bermula dari $U$-Shape Line atau lebih dikenal dengan nine-dashed line yang merupakan garis demarkasi yang digunakan pemerintah China untuk menandai kembali wilayah kedaulatan China. Diawali dari lepasnya Kepulauan Spratly dari kependudukan Jepang pasca PD II, China langsung melakukan klaim dengan istilah area memancing tradisional yang didasari sejarah pelayaran China pada masa Dinasti Ming. ${ }^{4}$ Garis demarkasi tersebut juga mengikutsertakan Kepulauan

\footnotetext{
${ }^{1}$ Moch Faisal Karim, "Middle Power, status-seeking and role conceptions: the cases of Indonesia and South Korea," Australian Journal of International Affairs, Maret 2018, 1-21, https://doi.org/10.1080/10357718.2018.1443428.

${ }^{2}$ David Rosenberg, "Governing the South China Sea : From Freedom of the Seas to Ocean Enclosure Movements," South China Sea, t.t., http://www.southChinasea.org/files/2013/02/Governing_The_South_China_Sea.pdf.

${ }^{3}$ Robert D. Kaplan, "Why South China Sea is so crucial?," Bussiness Insider, 20 Februari 2015, diakses pada 2015 April 2018, https://www.businessinsider.com.au/why-the-southChina-sea-is-so-crucial-2015-2.

4 Asnani Usman dan Risal Sukma, Konflik Laut China Selatan, Tantangan Bagi ASEAN (Jakarta: Centre for Strategic and International Studies, 1997).
} 
Dongsha, Zousha yang diperebutkan baik seluruhnya atau sebagian oleh China, Filipina, Malaysia, Taiwan dan Vietnam; serta Kepulauan Paracel (Xisha) yang diperebutkan Vietnam, China dan Taiwan. ${ }^{5}$

Sengketa diwarnai dengan belasan insiden bersenjata antara nelayan China dan angkatan bersenjata negara anggota ASEAN yang bersengketa seperti Malaysia, Filipina dan Vietnam. ${ }^{6}$ Sedangkan Brunei Darussalam lebih menunjukkan sikap pertahanan pasif. Menyadari potensi konflik, Indonesia sudah mengupayakan penyelesaian batas wilayah di LCS sejak 1992. Indonesia menyadari tidak adanya sengketa wilayah antara RI dan China dapat memberikan posisi menguntungkan bagi Jakarta untuk berperan memimpin penyelesaian konflik untuk stabilitas kawasan. Untuk itu Indonesia menyatakan posisi politik luar negerinya di LCS yaitu non-claimant state, honest broker, mengedepankan penyelesaian sengketa secara damai serta penegakan hukum internasional. ${ }^{7}$ Walaupun dalam penyelesaian konflik, China melakukan pembangunan infrastruktur militer China di sekitar Kepulauan Spratly yang berjarak tidak lebih dari 500 kilometer di utara Selat Karimata. ${ }^{8}$ Tindakan agresif ini diperlihatkan dengan pembangunan landasan udara militer sepanjang 3.000 meter dan reklamasi pulau untuk penempatan pesawat intai udara serta peningkatan kapabilitas militer besar-besaran khususnya angkatan laut, dengan CCG sebagai the third navy yang mengamankan klaim China di LCS. ${ }^{9}$ Lewat posisinya Indonesia mendorong negara-negara yang bersengketa untuk menahan diri dalam menghadapi tindakan agresif ini.

\footnotetext{
${ }^{5}$ Roach, "Malaysia and Brunei: An Analysis of Their Claims in the South China Sea," t.t.

${ }^{6}$ I Nyoman Sudira, "Konflik Laut China Selatan dan Politik Luar Negeri Indonesia ke Amerika dan Eropa," Universitas Katolik Parahyangan 10, no. 2 (2014).

7 Tim Posisi Dasar BPPK Kemlu, Posisi Dasar Kebijakan Luar Negeri Indonesia 2016 (Badan Pengkajian dan Pengembangan Kebijakan (BPPK) Kementerian Luar Negeri, 2016).

${ }^{8}$ Clive H. Schofield dan William G. Stormont, "An Arms Race in the South China Sea?," The University of Chicago 12, no. 1 (1996): 286-305.

${ }^{9}$ Andrew S. Erickson, "The Growth of China's Navy : Implication for Indian Ocean Security," dalam Strategic Analysis, vol. 32, 4 (London: Routledge, 2008), 655-76.
}

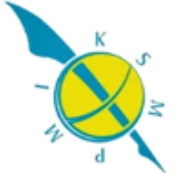


Hingga tahun 2013 basis militer RI di Natuna tidak menunjukkan bentuk pertahanan yang aktif. Hal ini ditunjukan dengan tidak adanya pesawat intai udara di pangkalan udara Ranai serta kurangnya patroli laut yang dilakukan baik AL maupun Badan Keamanan Laut RI di perairan sekitar kepulauan terdepan Indonesia itu. Agresivitas dan tindakan konfliktual militer China di LCS terlihat tidak ditujukan kepada Indonesia. Apalagi mengacu pada tahun 2012 RI-China baru menyepakati Mou Kerja Sama yang mengedepankan keamanan maritim dan menghargai kedaulatan maritim masing-masing negara. Jakarta seakan percaya diri bahwa pembangunan basis militer China tidak akan memberi ancaman berarti bagi kedaulatan Indonesia.

\section{Kerangka Pemikiran}

Tulisan ini akan meneliti bagaimana Indonesia menggunakan deterrence di Natuna sebagai instrumen politik luar negerinya untuk melindungi kepentingan nasional yaitu kedaulatan dan stabilitas kawasan. Sebagai strategi, deterrence dilihat sebagai pilihan tindakan yang mengabungkan 2 kepentingan yang bersaing, melawan musuh dan menghindari perang. Tujuannya yaitu melakukan proteksi terhadap kepentingan yang bersifat spesifik, namun tidak menciptakan konflik yang lebih luas. ${ }^{10}$ Deterrence juga merupakan salah satu instrumen politik luar negeri untuk mencapai kepentingan nasional.

Sebelum melakukan pembahasan mengenai bagaimana deterrence sebagai instrumen politik luar negeri Indonesia menunjukan karakteristik negara middle power, kita perlu mengerti apa itu politik luar negeri. Politik (kebijakan) luar negeri merupakan suatu rumusan kebijakan yang akan menjadi landasan yang akan 'melegalkan' tindakan negara (act of state) dalam melakukan hubungan internasional. Rumusan kebijakan ini merupakan perpanjangan tangan dari kebijakan domestik yang diimplementasikan dalam hubungan eksternal dan akan

\footnotetext{
${ }^{10}$ Alexander L. George dan Richard Smoke, "Deterrence and Foreign Policy," World Politics 41, no. 02 (1989): 170-82.
} 
menjadi dasar yang mengatur hubungan bilateral dan multilateral hingga menentukan posisi negara tersebut dalam isu-isu internasional. Oleh karena itu PLN harus bersifat universal sekaligus fleksibel dalam menghadapi ketidakpastian politik internasional dan mengejari kepentingan nasional yang juga dinamis.

Sedangkan Power dalam hubungan internasional dikenal sebagai salah satu konsep teori realisme. Realisme menjelaskan bahwa power dapat menjadi tujuan utama kepentingan negara atau negara justru menggunakan power sebagai alat untuk mengejar kepentingaan nasional yang lain. Pada umumnya power dibagi menjadi small power, middle power dan major power yang dibedakan dari kapasitas negara itu sendiri. Power negara dapat diperlihatkan dari dua sisi yaitu status dan peran. ${ }^{11}$ Power sebagai status dilihat dari kekuatan militer dan kapasitas ekonomi. Namun tulisan ini akan spesifik membahas power dalam kerangka politik luar negeri. Bagi studi PLN, untuk memperlihatkan power dalam terms peran, kita harus memperhatikan implementasi dari karakteristik politik luar negeri negara itu sendiri, apakah PLN tersebut berjalan beriringan dengan status power yang disandang negara tersebut. ${ }^{12}$

Kembali kepada konsep karakteristik PLN berdasarkan power yang dimiliki negara, tulisan ini akan fokus kepada karakteristik politik luar negeri negara middle power. Menurut Copper, Hoggat dan Nossal negara middle power memiliki karakteristik politik luar negerinya sendiri. Middle Power dikategorikan menjadi dua traditional dan emerging middle power. Traditional middle powers seperti Australia dan Kanada sudah memiliki industrialisasi ekonomi yang stabil dan pendapatan per kapita yang tinggi; berbeda dengan emerging middle power seperti Indonesia yang masih merupakan negara semi-periferi. Karakteristik negara sebagai emerging middle power ditunjukan dengan niche diplomacy, good international citizenship, mediator, coalition building dan norm diffuser. Tindakan ini dilakukan

\footnotetext{
${ }^{11}$ Karim, "Middle Power, status-seeking and role conceptions : the cases of Indonesia and South Korea."

${ }^{12}$ Karim.
} 
middle power semata-mata untuk melakukan proteksi terhadap status-quo karena middle power sangat membutuhkan iklim investasi yang stabil.

Tulisan ini akan menganalisa bagaimana deterrence yang dilakukan berada dalam kerangka konsep niche diplomacy dan coalition building yang mencerminkan politik luar negeri negara middle power.

\section{Pelanggaran Domain Pertahanan NKRI di Natuna}

Pasca Xi Jinping menduduki kursi pemerintahan, China menunjukkan sikap agresif dalam melindungi klaimnya di LCS. Tahun 2013 China memperlihatkan intensinya di Natuna. Xi Jinping lewat SinoMap Press memperlihatkan adanya tumpang tindih wilayah kedaulatan di ZEE Natuna. ${ }^{13}$ Menlu China juga menyatakan bahwa RI dan China perlu menyelesaikan sengketa maritim. Ini seakan menunjukkan China memulai sengketa wilayah baru dengan Indonesia.Sepanjang tahun 2016, tercatat sudah ada 3 insiden yang terjadi di perairan Natuna antara CCG dan TNI/Bakamla. Pada tanggal 17 Juni 2017, Kapal Perang TNI Angkatan Laut (KRI) Imam Bonjol-383 menerima laporan intai udara maritim bahwa ada 12 kapal ikan asing yang berlayar di perairan Natuna dan mencuri ikan, yang diantaranya adalah kapal China. ${ }^{14}$ Pada 19 Maret 2016, juru bicara Kemlu RI, Armanatha Nasir menyampaikan bahwa kapal yang ditugaskan khusus oleh Kementerian Kelautan dan Perikanan Indonesia menangkap sebuah kapal nelayan di dalam ZEE Indonesia di lepas pantai Natuna. ${ }^{15}$ Otoritas keamanan Indonesia langsung mengamankan 1 kapten kapal dan 8 ABK dan menarik kapan ke

\footnotetext{
${ }^{13}$ Victor Robert Lee, "Is Indonesia Beijing's Next Target in the South China Sea?," The Diplomat, Oktober 2014, https://thediplomat.com/2014/10/is-indonesia-beijings-nexttarget-in-the-south-china-sea/.

14 Anggi Kusumadewi, "Perairan Natuna, 'Medan Tempur' Indonesia-China", CNN Indonesia, 20 Juni 2016, diakses pada 20 September 2017, https://www.cnnindonesia.com/nasional/20160620170157-20-139564/perairan-natunamedan-tempur-indonesia-China/.

15 "Cina bantah kapal penjaga pantai masuki wilayah Indonesia," BBC Indonesia, 21 Maret 2016,

http://www.bbc.com/indonesia/dunia/2016/03/160321_dunia_cina_indonesia_natuna.
}

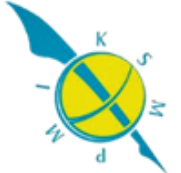


pangkalan Natuna, penangkapan dilakukan pukul 10 pagi dan diikuti dengan kedatangan CCG yang muncul untuk menyelematkan kapal nelayan tersebut. ${ }^{16}$ Pada hari Senin, 21 Maret 2016 melalui juru bicara kementerian luar negerinya, China menjelaskan bahwa kapal nelayan Kway Fey 10078 tidak melanggar garis perbatasan Indonesia karena lokasi tersebut merupakan wilayah memancing tradisional China. Selain itu, pengawalan CCG terhadap Kway Fey juga tidak melanggar garis batas teritorial. ${ }^{17}$

Pada Mei 2016, giliran AL yang mendapati adanya kapal nelayan China di ZEE Indonesia. Penangkapan kapal berbendera China, Gui Bei Yu dengan nomor lambung 27088 dilakukan oleh Kapal Republik Indonesia (KRI) Oswald Siahaan $354 .{ }^{18}$ Baku tembak pun terpaksa dilakukan karena sebelumnya peringatan tidak dihiraukan. Kapal pun akhirnya dibawa ke Pangkalan Angkatan Laut Natuna untuk pemeriksaan hukum. .Hanya berselang 1 bulan, KRI Imam Bonjol memergoki adanya kapal nelayan dengan nomor lambung 19038 yang kembali menangkap ikan di perairan Kepulauan Natuna. Kali ini pemeriksaan kapal nelayan dilakukan dengan menurunkan tim Visit Board Search and Seizure (VBSS) untuk memeriksa ABK. ${ }^{19}$ Dengan keamanan Natuna yang rentan ini, politik luar negeri Indonesia pun ditantang untuk memastikan keamanan Natuna tanpa memperkeruh konflik wilayah LCS dan tetap membangun relasi baik dengan Beijing.

\footnotetext{
16 Joe Cochrane, "China's Coast Guard Rams Fishing Boat to Free It From Indonesian Authorities," The New York Times, 21 Maret 2016, https://www.nytimes.com/2016/03/22/world/asia/indonesia-south-china-sea-fishingboat.html.

${ }^{17}$ Cochrane.

18 "Pengarmarbar Konfrensi Pers Terkait Penangkapan Kapal Ikan China," Tentara Nasional Indonesia, diakses 25 Maret 2018, http://www.tni.mil.id/view-97264-pangarmabarkonfrensi-pers-terkait-penangkapan-kapal-ikan-china.html.

19 "TNI AL Kembali Tangkap Kapal Ikan Berbendera Tiongkok," Tentara Nasional Indonesia, diakses 25 Maret 2018, http://www.tni.mil.id/view-98268-tni-al-kembali-tangkap-kapalikan-berbendera-tiongkok.html.
} 


\section{Indonesia Merespon}

Insiden-insiden diatas menjadi bukti lemahnya pertahanan RI teruatama pada Komando Armada Indonesia Kawasan Barat (Koarmabar). Kementerian Pertahanan pun berbenah dengan memprioritaskan anggaran kemhan sejumlah 108,7 triliun rupiah untuk penguatan pangkalan militer di Ranai, Natuna. ${ }^{20}$ Penguatan ini difokuskan pada pemeliharaan dan perbaikan Kapal Republik Indonesia (KRI), penambahan Alat Utama Sistem Senjata (Alutsista) dan penempatan satu Batalion Pasukan Khas (Paskhas). Tidak hanya itu, pembangunan infrastruktur militer juga dilakukan dengan meningkatkan status Landasan Udara Ranai dari tipe $\mathrm{C}$ ke tipe $\mathrm{B}$, ini artinya frekuensi wilayah pengamanan lanud meluas dan lanud akan disiapkan untuk penempatan pesawat termpur seperti F-16, Hawk 109 dan 209. ${ }^{21}$ Peningkatan status pangkala ini juga berarti penambahan anggota TNI yaitu satu kompi marinir TNI AD, satu kompi Paskhas TNI AU dan satu batalyon satuan AS akan dipindahtugaskan ke Natuna. Tambahan 3 unit Fregat dan satu Sea Rider juga ditempatkan di Natuna. ${ }^{22}$ Instalasi radar pengawas juga dibangun di Desa Tanjung Payung,sedangkan di Tanjung Datuk ditempatkan Multiple Launch Rocket System (MLRS). ${ }^{23}$ Bahkan dalam masterplan peningkatan kapabilitas kapal selam akan dilakukan dan kedepannya akan dibangun dermaga bungker kapal selam di Tanjung Sekalung. ${ }^{24}$ Kemhan ingin memastikan bahwa TNI di Natuna mampu menjadi Pasukan Pemukul Reaksi Cepat (PPRC) bersama dengan

\footnotetext{
20 Prima Gumilang, "Kemhan Prioritaskan Anggaran untuk Pangkalan Militer Natuna," CNN Indonesia, 1 Juli 2016, https://www.cnnindonesia.com/nasional/20160701164757-20142477/kemhan-prioritaskan-anggaran-untuk-pangkalan-militer-natuna.

${ }^{21}$ Zam Jambak, "Pangkalan Udara Ranai Segera Ditingkatkan Menjadi Tipe B," Antara, Desember 2016, https://kepri.antaranews.com/berita/36202/pangkalan-udara-ranaisegera-ditingkatkan-menjadi-tipe-b.

22 A Ziyadi, "Rincian Alutsista Pangkalan TNI di Natuna," Militermeter, Oktober 2016, http://militermeter.com/rincian-alutsista-pangkalan-tni-di-pulau-natuna/.

${ }^{23}$ Ziyadi.

${ }^{24}$ Emanuele Scimia, "Indonesia boots its air and sea denial capabilities," Asia Times, 20 November 2017, http://www.atimes.com/indonesia-boosts-air-sea-denial-capabilities/.
} 
pangkalan TNI AU Supadio di Pontianak yang akan menjadi pertahanan terdepan sebelum musuh memasuki teritorial Indonesia lebih jauh.

Respon ini juga bertepatan dengan latihan perang gabungan rutin yang dilakukan TNI AL-AD dan TNI-AU. Latihan Perang Angkasa Yudha tahun 2016 dimana terdapat unsur-unsur penerjunan pengendali tempur, pertempuran udara, operasi serangan udara strategis (OSUS), operasi lawan udara ofensif (OLUO), serangan udara langsung (SUL), bantuan tembakan udara (BTU), penerjunan logistik atau cargo dropping system (CDS). ${ }^{25}$ Latihan tempur pada dasarnya mengirim pesan diplomatik dan militer yaitu mengenai kesiapan tempur sebuah angkatan perang. Selain itu, secara halus Jakarta juga menyatakan bahwa China harus menghentikan ambisi maritimnya di ZEE Indonesia dengan memutuskan nama baru untuk wilayah Laut China Selatan yang berada di utara Kepulauan Natuna menjadi Laut Natuna Utara. ${ }^{26}$ Pemberian nama baru ini Jakarta memperlihatkan presistensinya bahwa Indonesia tidak memiliki sengketa maritim dengan China dan wilayah yang disengketakan China murni merupakan ZEE Indonesia. Dengan kata lain, kedaulatan wilayah Indonesia tidak untuk dinegosiasikan.

\section{Analisis : Konsistensi Indonesia sebagai Middle Power}

Sejak kemerdekaan Indonesia, pembuat kebijakan sudah mempertimbangan sumber-sumber power dan kepentingan nasional Indonesia pada saat itu; yakni pengakuan internasional dan bantuan ekonomi. Pertimbangan ini akhirnya menghasilkan Bebas-Aktif sebagai politik luar negeri Indonesia dan menjadi dasar tindakan negara serta menunjukkan posisi negara dalam isu-isu kerja sama maupun konflik internasional, termasuk konflik Laut China Selatan. Tindakan konfliktual

\footnotetext{
25 “Pasukan Khas TNI AU Rebut Pangkalan," Tentara Nasional Indonesia, diakses 25 Maret 2018, http://www.tni.mil.id/view-103393-pasukan-khas-tni-au-rebut-pangkalan.html.

${ }^{26}$ Tiara Sutari, "China dan Arti Sebuah Nama Laut di Utara Natuna," CNN Indonesia, 21 Juli 2017, https://www.cnnindonesia.com/nasional/20170721095355-20-229358/china-danarti-sebuah-nama-laut-di-utara-natuna.
} 
CCG China di Laut Natuna memperlihatkan adanya ambisi China untuk mengubah status-quo di LCS dan menantang posisi Indonesia sebagai honest broker. Dilihat dari sudut pandang karakteristik middle power, middle power akan menghindari konflik terbuka dengan major power, dalam hal ini Indonesia tidak mau mengakui adanya sengketa maritim dengan China. Walaupun secara terang-terangan Beijing menyampaikan bahwa RI-China memiliki tumpang tindih kedaulatan. Presistensi Indonesia menyebabkan konflik hanya diakui oleh pihak Beijing saja. Keinginan Beijing untuk menyelesaikan sengketa maritim dengan Indonesia secara bilateral pun tidak ditanggapi Jakarta. Jakarta tetap pada pendirian bahwa sengketa LCS tidak menyentuh Indonesia sehingga China seharusnya menyelesaikan sengketa perbatasannya dengan kelima negara lain yang bersengketa, bukan Indonesia.

Menanggapi illegal fishing, Indonesia sadar lemahnya kemampuan pertahanan perbatasan di Natuna yang menjadi pintu masuk LCS. Lewat pernyataan Menteri Luar Negeri Retno Marsudi, Indonesia menyatakan bahwa penguatan militer di Pulau Natuna tidak dilakukan untuk menyatakan sikap perlawanan terhadap China, tapi untuk memperlihatkan bahwa ZEE Indonesia di Natuna adalah teritorial Indonesia yang sah dan tidak terbantahkan. Selain itu Natuna juga menjadi konsentrasi pembangunan pulau terluar sebagai implementasi Kebijakan Poros Maritim Dunia di era pemerintahan Joko Widodo. ${ }^{27}$ Keamanan maritim harus ditingkatkan untuk mengawal perdagangan internasional dan investasi yang melewati laut. Sehingga kekuatan militer disini bertugas untuk mengamankan jalannya aktivitas perekonomian Indonesia. Dalam kerangka kerja Poros Maritim Dunia, peningkatan kapabilitas militer yang dilakukan merupakan bentuk people based diplomacy yang dicanangkan Kementerian Luar Negeri bersama Retno Masurdi. Artinya, hasil diplomasi dan implementasi politik luar negeri (dalam hal ini keamanan maritim) harus dapat dirasakan rakyat dan memberi kesejahteraan.

\footnotetext{
27 “Latihan Tempur Angkasa Yudha 2016 di Kawasan Natuna," Presiden RI, Oktober 2016, http://presidenri.go.id/berita-aktual/latihan-tempur-angkasa-yudha-2016-di-kawasannatuna.html.
} 
Dengan jelas Indonesia menyatakan bahwa hasil laut Natuna harus dapat dieksplorasi untuk kesejahteraan nelayan dan bukan untuk ambisi kekuasaan pihak eksternal. Melihat Kebijakan Poros Maritim Dunia, jelas ini merupakan niche diplomacy Indonesia di era Jokowi.

Niche diplomacy merupakan diplomasi spesifik yang dilakukan negara middle power untuk mendapat atensi dunia, mengamankan kepentingannya serta menegaskan arah kerja sama internasionalnya.

Bagi kasus Natuna penempatan kekuatan militer dan reaksi cepat militer bukan untuk unjuk gigi Indonesia terhadap mojor power tapi merupakan bagian dari kerangka kerja Poros Maritim Dunia untuk menciptakan perairan yang aman untuk kesejahteraan nelayan dan peningkatan ekspor ikan. Selain itu, pergantian nama Laut Natuna Utara juga bukanlah hal yang perlu di besar-besarkan karena penggunaan nama Laut Natuna Utara sudah digunakan warga lokal dan Indonesia berhak atas perubahan nama tersebut. Walaupun hanya 2 hari setelah pernyataan Indonesia lewat Kementerian Koordinator Bidang Kemaritiman, China langsung menunjukkan langkah Indonesia dapat memperkeruh konflik. ${ }^{28}$ Tapi Indonesia tetap tidak terpengaruh. Dalam pemerintahan Joko Widodo Indonesia mampu memperlihatkan diplomasi middle power melalui diplomasi poros maritim dunia yang ternyata pembangunannya memiliki efek penggentar. Hal ini sejalan dengan konsep middlepowermanship yang mengatakan bahwa salah satu karakteristik politik luar negeri middle power adalah dengan menunjukkan niche diplomacy.

Untuk itu dapat dilihat bentuk deterrence yang dilakukan berada dalam jalur kerangka pembangunan Indonesia sebagai implementasi Kebijakan Poros Maritim. Sebagai aktor rasional, Indonesia mempertimbangan dua kepentingan yang tetap harus dicapai. Indonesia memiliki kepentingan barupa pertahanan kedaulatan sekaligus merangkul China sebagai rekan investasi. Jika Indonesia menunjukkan konfrontasi dengan China dan mengakui adanya sengketa wilayah, Indonesia akan kehilangan citra sebagai honest broker dan menurunkan harga diri

\footnotetext{
${ }^{28}$ Sutari, "China dan Arti Sebuah Nama Laut di Utara Natuna."
}

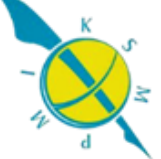


Indonesia dalam mempertahankan wilayahnya. Disamping itu, jika Indonesia menyatakan sikap konfrontatif maka ASEAN tidak lagi mampu menunjukkan kemampuannya memediasi konflik. Ketidakhadiran negara yang mampu mengupayakan penyelesaian konflik secara damai dan bertindak sebagai mediator di kawasan akan mengundang Amerika Serikat sebagai aktor eksternal untuk ikut campur secara langsung di LCS. Mengingat LCS juga merupakan kawasan investasi yang menjadi konsentrasi keamanan AS dan sekarang ini Vietnam dan Filipina sudah menggandeng AS untuk melawan China. Jika AS semakin involve di LCS, ditakutkan LCS akan menjadi kawasan arms race kekuatan-kekuatan besar dan justru tidak menguntungkan bagi iklim investasi.

Melalui pertimbangan ini, diplomasi middle power harus dilakukan, diplomasi yang menunjukkan posisi sebagai mediator, jembatan antara kekuatan besar dan negara-negara ASEAN yang bersengketa serta menegakan hukum internasional yang ada. Keinginan indonesia untuk mampu menyediakan keamanan dan menciptakan stabilitas di konflik LCS tanpa mengikutsertakan AS, karna ditakutkan akan menyebabkan arms race di kawasan. Dikala negara-negara yang bersengketa seperti Singapura, Filipina dan menggandeng pihak ketiga yaitu AS. Berbeda dengan Indonesia yang yang selalu mengejar independent defence and security policy. Walaupun Indonesia melakukan hubungan pertahanan dengan AS dan Jepang dalam bidang asistensi, pembelian senjata dan operational coordination, namun hal ini tidak terlalu berdampak pada tantangan konflik di sekitar Kepulauan Natuna. ${ }^{29}$ Mengedepankan diplomasi dan negosiasi dalam setiap peneyelesaian konflik, Jakarta menunjukkan optimismenya untuk tetap menjadikan ASEAN sebagai garda terdepan penyelesaian konflik.

Peningkatan militer di Natuna bisa saja menciptakan dilema keamanan kawasan. Namun, sekali lagi Indonesia memperlihatkan karakteristiknya sebagai middle power dengan menunjukkan kesediaan menyelesaikan tumpang tindih

${ }^{29}$ Ian Bowers, "Power Asymmetry and the Role of Deterrence in the South China Sea," Norwegian Institute for Defence Studies 29, no. 4 (2017): 551-73. 
perbatasan dengan Thailand, Malaysia, Singapura, Vietnam dan Filipina melalui border diplomacy yang masih dalam kerangka kerja diplomasi Poros Maritim Dunia. Perundingan batas wilayah yang intesif memperlihatkan keinginan Indonesia menyelesaikan masalah dengan negosiasi dan tidak menunjukkan tendensi untuk mengubah status-quo lewat pembangunan kapabilitas militernya. Pembangunan militer dilakukan murni untuk keamanan maritim dan juga mengejar minimum essential force (MEF) $2024 .{ }^{30}$ Kesepakatan segmen baru perbatasan wilayah dengan Malaysia, Singapura dan Filipina pun berhasil dilakukan. ${ }^{31}$ Selain memperlihatkan kesediaan menghormati batas teritorial masing-masing negara, border diplomacy ini juga dapat dilihat sebagai coalition building antara Indonesia dengan negara-negara ASEAN yang memiliki sengketa di LCS. Dalam roadmap diplomasi perbatasan ini juga Indonesia memaparkan bahwa Indonesia tidak memiliki tumpang tindih kedaulatan dengan China, dan sengketa maritim yang dikatakan China tidak berdasar. ${ }^{32}$ Indonesia konsisten mendorong China untuk menyelesaikan sengketa maritim melalui jalur multilateral.

\section{Kesimpulan}

Berdasarkan pemaparan diatas, dapat dilihat niche diplomacy dibawah kepemimpinan Jokowi yaitu diplomasi yang menunjukkan karakteristik bangsa Indonesia sebagai negara maritim. Ketika China menunjukkan intensinya untuk mengubah status-quo di LCS, kepentingan nasional Indonesia tetap konsisten memainkan peran middle power yang ditunjukan dengan respon deterrence berupa peningkatan kapabilitas militer dan pembangunan infrastruktur militer di Natuna. Penggentaran juga dilakukan dalam porsi yang tepat dan ditujukan jelas sebagai

\footnotetext{
30 "Minimum Essential Force TNI Tahap 2 (2015-2019)," Jakarta Greater, t.t., https://jakartagreater.com/minimum-essential-force-tni-tahap-2-2015-2019/.

31 Sonya Michaella, "Kemenlu Paparkan Pencapaian RI dalam Konflik Batas Wilayah," Metrotvnews, 7 Januari 2016, http://internasional.metrotvnews.com/asia/8ko21eWbkemenlu-paparkan-pencapaian-ri-dalam-konflik-batas-wilayah.

32 Tim Posisi Dasar BPPK Kemlu, Posisi Dasar Kebijakan Luar Negeri Indonesia 2016.
}

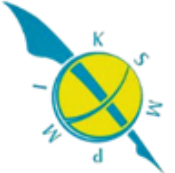


cara Indonesia mengamankan teritorialnya bukan untuk memperkeruh konflik LCS, menantang status-quo ataupun justru menciptakan dilema keamanan bagi negaranegara sahabat Indonesia di ASEAN. Sehingga respon deterrence yang dilakukan merupakan implementasi dari niche diplomacy itu sendiri, salah satunya keamanan maritim. Berjalan bersama peningkatan kapabilitas militer, Indonesia juga berperan pada coalition building menyelesaikan sengketa perbatasan melalui diplomasi yang menunjukkan niat baik Indonesia dalam menghormati teritorial masing-masing negara dan peran aktif Indonesia menjaga keamanan maritim untuk stabilitas ekonomi kawasan. Dengan coalition building ini Indonesia memperlihatkan negaranegara ASEAN sudah mencapai kesepakatan teritorial dan menunjukkan China adalah aktor yang harus mampu merem ambisi maritimnya. Lebih jauh, dengan dorongan Indonesia, ASEAN mampu menjadi lembaga yang memediasi konflik. Hal ini tentu mengurangi tendensi negara-negara ASEAN yang bersengketa untuk mencari bantuan keamanan pada pihak ketiga, yaitu AS. Hal ini tentu saja mengurangi kemungkinan arms race antara kedua kekuatan besar di LCS dikemudian hari.

Oleh karena itu, melalui respon Indonesia China dapat melihat kekuatan diplomasi Indonesia dan karakteristik Indonesia sebagai negara middle power yang mampu menjaga domain kedaulatannya. Namun tetap memposisikan diri sebagai mediator dan coalition builder yang melakukan proteksi terhadap status-quo untuk mencapai stabilitas kawasan.

\section{Daftar Pustaka}

Alexander L. George, dan Richard Smoke. "Deterrence and Foreign Policy.” World Politics 41, no. 02 (1989): 170-82.

Bowers, Ian. "Power Asymmetry and the Role of Deterrence in the South China Sea.” Norwegian Institute for Defence Studies 29, no. 4 (2017): 551-73.

“Cina bantah kapal penjaga pantai masuki wilayah Indonesia.” BBC Indonesia, 21 Maret 2016.

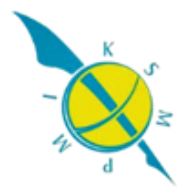


http://www.bbc.com/indonesia/dunia/2016/03/160321_dunia_cina_indonesia _natuna.

Cochrane, Joe. “China's Coast Guard Rams Fishing Boat to Free It From Indonesian Authorities." The New York Times, 21 Maret 2016. https://www.nytimes.com/2016/03/22/world/asia/indonesia-south-china-seafishing-boat.html.

Erickson, Andrew S. “The Growth of China's Navy : Implication for Indian Ocean Security.” Dalam Strategic Analysis, 32:655-76. 4. London: Routledge, 2008.

Gumilang, Prima. "Kemhan Prioritaskan Anggaran untuk Pangkalan Militer Natuna." CNN Indonesia, 1 Juli 2016.

https://www.cnnindonesia.com/nasional/20160701164757-20-

142477/kemhan-prioritaskan-anggaran-untuk-pangkalan-militer-natuna.

Jambak, Zam. "Pangkalan Udara Ranai Segera Ditingkatkan Menjadi Tipe B.” Antara, Desember 2016.

https://kepri.antaranews.com/berita/36202/pangkalan-udara-ranai-segeraditingkatkan-menjadi-tipe-b.

Kaplan, Robert D. “Why South China Sea is so crucial?” Bussiness Insider, 20 Februari 2015. https://www.businessinsider.com.au/why-the-south-china-seais-so-crucial-2015-2.

Karim, Moch Faisal. "Middle Power, status-seeking and role conceptions : the cases of Indonesia and South Korea.” Australian Journal of International Affairs, Maret 2018, 1-21. https://doi.org/10.1080/10357718.2018.1443428.

"Latihan Tempur Angkasa Yudha 2016 di Kawasan Natuna.” Presiden RI, Oktober 2016. http://presidenri.go.id/berita-aktual/latihan-tempur-angkasa-yudha2016-di-kawasan-natuna.html.

Lee, Victor Robert. "Is Indonesia Beijing's Next Target in the South China Sea?" The Diplomat, Oktober 2014. https://thediplomat.com/2014/10/is-indonesiabeijings-next-target-in-the-south-china-sea/.

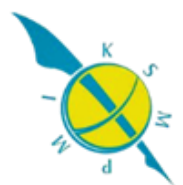


Michaella, Sonya. "Kemenlu Paparkan Pencapaian RI dalam Konflik Batas

Wilayah.” Metrotvnews, 7 Januari 2016.

http://internasional.metrotvnews.com/asia/8ko21eWb-kemenlu-paparkanpencapaian-ri-dalam-konflik-batas-wilayah.

“Minimum Essential Force TNI Tahap 2 (2015-2019).” Jakarta Greater, t.t. https://jakartagreater.com/minimum-essential-force-tni-tahap-2-2015-2019/.

"Pasukan Khas TNI AU Rebut Pangkalan.” Tentara Nasional Indonesia. Diakses 25 Maret 2018. http://www.tni.mil.id/view-103393-pasukan-khas-tni-au-rebutpangkalan.html.

"Pengarmarbar Konfrensi Pers Terkait Penangkapan Kapal Ikan China.” Tentara Nasional Indonesia. Diakses 25 Maret 2018. http://www.tni.mil.id/view97264-pangarmabar-konfrensi-pers-terkait-penangkapan-kapal-ikanchina.html.

Roach. "Malaysia and Brunei: An Analysis of Their Claims in the South China Sea," t.t.

Rosenberg, David. "Governing the South China Sea : From Freedom of the Seas to Ocean Enclosure Movements." South China Sea, t.t. http://www.southchinasea.org/files/2013/02/Governing_The_South_China_S ea.pdf.

Schofield, Clive H., dan William G. Stormont. "An Arms Race in the South China Sea?" The University of Chicago 12, no. 1 (1996): 286-305.

Scimia, Emanuele. "Indonesia boots its air and sea denial capabilities." Asia Times, 20 November 2017. http://www.atimes.com/indonesia-boosts-air-sea-denialcapabilities/.

Sudira, I Nyoman. "Konflik Laut China Selatan dan Politik Luar Negeri Indonesia ke Amerika dan Eropa." Universitas Katolik Parahyangan 10, no. 2 (2014).

Sutari, Tiara. "China dan Arti Sebuah Nama Laut di Utara Natuna." CNN Indonesia, 21 Juli 2017. 
https://www.cnnindonesia.com/nasional/20170721095355-20-229358/chinadan-arti-sebuah-nama-laut-di-utara-natuna.

Tim Posisi Dasar BPPK Kemlu. Posisi Dasar Kebijakan Luar Negeri Indonesia 2016. Badan Pengkajian dan Pengembangan Kebijakan (BPPK) Kementerian Luar Negeri, 2016.

“TNI AL Kembali Tangkap Kapal Ikan Berbendera Tiongkok.” Tentara Nasional Indonesia. Diakses 25 Maret 2018. http://www.tni.mil.id/view-98268-tni-alkembali-tangkap-kapal-ikan-berbendera-tiongkok.html.

Usman, Asnani, dan Risal Sukma. Konflik Laut China Selatan, Tantangan Bagi ASEAN. Jakarta: Centre for Strategic and International Studies, 1997.

Ziyadi, A. "Rincian Alutsista Pangkalan TNI di Natuna." Militermeter, Oktober 2016. http://militermeter.com/rincian-alutsista-pangkalan-tni-di-pulaunatuna/. 